\title{
8 In the name of constitutionalism and Islam
}

\author{
The murky world of labour politics \\ in Calcutta's docklands
}

\author{
Prerna Agarwal
}

In December 1934, thousands of dockers disrupted imperial trading that passed through the Port of Calcutta. ${ }^{1}$ They went on a strike, part of a series, for shorter working hours across the various ports in British India. Even though the demands of workers were in consonance with the recommendations of an imperial inquiry, the Royal Commission of Labour, the legitimacy of the strike as a "genuine" labour dispute dominated the official and public discourse. It being admitted only as an official afterthought (in confidential documents) that the strike was, in fact, a success from the point of view of workers.

The strike was led by a newly formed red-flag union known as Calcutta Port and Dock Workers' Union (CPDWU) with several nationalist-revolutionaries, communists and socialists in its leading body. ${ }^{2}$ The colonial state perceived the strike as announcing the resumption of radical activity in Calcutta, in the aftermath of the Meerut Conspiracy Trial. ${ }^{3}$ The radical leaders of CPDWU were arrested for sedition, strike pickets were violently repressed and CPDWU was declared an unlawful organisation along with several other labour and communist organisations. Such reactions reflected the deep anxieties of the colonial state faced with a militant labour movement, which was charged with revolutionary symbols and was associated with a range of self-identified revolutionaries in communist, socialist and nationalist traditions. ${ }^{4}$ This article assesses the responses of the colonial state and how these shaped the labour movement in Calcutta's docklands.

The responses of the colonial state must be placed into the context of its dilemmas regarding the labour question as it emerged in early twentieth century India. Since the aftermath of the First World War, non-existence of labour organisations and any kind of official machinery for the resolution of labour disputes was considered to be a problem. The vacuum in the trade union field was being filled by red-flag activists in several major industries, and this was to remain the main official concern throughout the interwar period. The dock strike of 1934 was one of the first successful strikes marking the revival of militant labour politics in Calcutta's industrial neighbourhoods and proving the inadequacy of the Meerut Trial in stamping out communist activity. As the imperial authorities stepped up the repression, even the existing Trade Union Act of 1926 appeared to be too liberal as it allowed the formation of radical trade unions. The peculiar problem that the government faced was summed up by the Trade Union Registrar of the 
Bengal Labour and Commerce Department thus: "I expect one day to receive an application from a union one of whose objects is to establish 'dictatorship of the proletariat', must I as a registrar, register the union?"5

Yet the imperial authorities were concerned that the repressive policies did not go against the "genuine" labour unions. ${ }^{6}$ But these were hardly to be found on the ground. In the largest industry of Bengal, jute mills, the influential trade unions were of two types: red-flag unions or white unions, the latter emerging as a real threat to the existence of militant unions in a number of industries. ${ }^{7}$ The white unions were characterised by their espousal of communal politics, which resulted in Hindu-Muslim riots multiple times. ${ }^{8}$ In fact, the mastermind behind the formation of these unions was the rising star of Muslim communal politics in Bengal, Huseyn Shaheed Suhrawardy. ${ }^{9}$ He would also come to hold the portfolio of Labour in the first provincial government of colonial Bengal (formed in 1937). The imperial authorities, it would seem, were cultivating conservative and communal trade unions, behind the scenes, even as they talked about the necessity of "genuine" trade unions.

The local allies of colonial rulers had different motivations for meddling in labour affairs. The emergence of labour militancy in the interwar period across industrial Calcutta threatened to unsettle the traditional authority of local clerics and politicians as well, at a time when Muslim communalist politics was gaining ground. The docklands were constituted by the poorest neighbourhoods of the city - Kidderpore, Mominpore and Watgang - also forming the largest concentration of working-class Muslims. ${ }^{10}$ The docklands thus had fallen in the purview of Muslim politicians since the beginning of the twentieth century. ${ }^{11}$ However, influential labour leaders among them were not always advocates of communalist politics or primarily used religion as a mobilisational tool. ${ }^{12}$ From the mid-1930s onward, the Bengal Muslim League rose as a cohesive and formidable political party on the basis of religious nationalism. This was part of the communalisation trends in anti-colonial politics, which culminated in a frenzy of Hindu-Muslim riots in 1946-47. ${ }^{13}$ It was in such a context that the dock neighbourhoods emerged central to popular mobilisation for communal politics, so much so that one historian even called Kidderpore as part of the "riot-zone of Calcutta". ${ }^{14}$ The dockers, predominantly of Muslim origin ${ }^{15}$ and migrants from UP, Bihar, particularly from the Darbhanga region, ${ }^{16}$ and Orissa, along with the boatmen had participated in major riots as early as $1926 .{ }^{17}$ The dockers as well as the seamen and the boatmen were thus to form an important constituency for a range of Muslim politicians looking to establish muscle power in the streets of Calcutta.

Taking a microhistory approach, this chapter focuses on the dock strike of 1934 and the modus operandi of dockers' unions. It largely relies on the intelligence documentation produced by the Special Branch of Calcutta Police, which recorded the everyday activities of radical political groups in the city's industrial districts in minute details. The records produced for the purposes of "keeping an eye" are highly abbreviated for the most part, but combined with occasional investigations which provide crucial detailing, enable us to place the accent on working-class agency, as well as reveal the murkier dimensions of labour politics. 
They allow a reflection on how labouring aspirations, anxieties and militancy were finding an outlet into a bewildering mix of political causes, including varied visions of anti-colonialism. It is thus that the vantage point of the docklands discloses the antinomies of the responses of colonial authorities towards the radicalisation of politics of labour. It draws attention to the acceleration of communalisation of politics in working-class districts in the decade preceding the Partition of India, as the colonial government formed alliances with Muslim Nationalists, in an attempt to resurrect a dangerous and consequential counterweight. The research shifts the attention away from Muslim politics as played out in the legislative assemblies, municipal corporation, party offices and drawing rooms, ${ }^{18}$ towards the streets of Calcutta's docklands, to highlight the embedding and congealing of political trends that would burst out into the open as the city was caught in between the Partition riots and waves of strikes in the post-war period.

\section{The strike}

The dock strike of 1934 had been planned for over six months and it initiated the establishment of a red-flag trade union at the Port: Calcutta Port and Dock Workers' Union (CPDWU). The dockers were employed as casual labour by stevedores through various contractors and not directly by the Calcutta Port Trust. In total, they numbered around 15,000-18,000 and were spread out in various parts of the port; a large number of them being unemployed at any given point. ${ }^{19}$

The strike must first be placed in a wider context. The Royal Commission of Labour had recommended limiting working hours at the docks to nine hours, with an allowance of three hours of paid overtime. ${ }^{20}$ However, these recommendations were to be partially implemented after the strikes at all major ports. Between October 1929 and November 1937, there were several strikes of dockworkers at all the Indian Ports - Karachi, Rangoon, Madras, Bombay, Calcutta and Bombay (in that order). ${ }^{21}$ In Calcutta, workers' demands included higher wages, shorter working hours, compensation for accidents and two days of leave in addition to government holidays. Separate demands for wages were formulated by the winchmen, the salt department and the chipping and painting department. ${ }^{22}$

In the winter of 1933, a few dockers of British India Steam Navigation, including the "pioneer" Mohammad Salim (a dockworker of Bombay), ${ }^{23}$ who had known Charles Mascerenhas, an early communist and an associate of M.N. Roy; ${ }^{24}$ a few members of the Labour Party, including one of its founders, Niharendu Dutt Mazumdar; and labour activists of M.N. Roy's newest organisation, the Indian Republican Party, decided to form a union of dockworkers and called it the Calcutta Port and Dock Workers' Union. ${ }^{25}$ The secretary of the union was Shishir Roy, of the famous Sarishabari Bomb case, who was now a member of a "communist - cum - terrorist" group. The president of the union was another dockworker, Sher Khan, a winchman (a skilled docker) from Bombay originally from Jalandhar, who is described as a "follower" of Rajani Mukherji, leader of the Calcutta section of M.N. Roy's organisation. Rajani Mukherji was vice-president 
along with Md. Yusuf, also a winchman and the president of the Bengal Labour Party. Santi Ram Mondal, an ex-railway clerk, who had been prominent in organising the Lilooah Railway workshop strike of 1928 was also amongst the leadership of this union. ${ }^{26}$ The profile of the union leadership indicates that the early communist groups attracted workers into their ranks. What's more, such workers were openly taking the risk of being associated with known communists and infamous revolutionary-terrorists. A few were even willing to travel across the country to organise other workers as was the case with Md. Salim; he was "a volunteer" of the Dock Workers' Union in Bombay and after his stint at the Calcutta docks, went to United Provinces to organise the peasants "under the instructions" of Mazumdar.

In the first meeting of the union, held in January 1934, radical speeches were made and red flags were hoisted. ${ }^{27} \mathrm{~A}$ series of regular meetings and demonstrations followed till the end of the year. Ideas attacking the state as the ' $m \bar{a}-b \bar{a} p$ '(motherfather) of the employers and not that of workers were discussed by the activists. The police were identified as the "fauj" (army) of the employers. It was said that the workers must organise their own fauj and even a government of their own. Mazumdar even argued that workers "could not allow the government to exist if it failed to stop molestation of the workers". Union leaders constantly asserted that the workers were capable of fighting without the aid of the government or the police, which were in fact considered the enemy. In one of these meetings, Mazumdar in his characteristic grandiose manner extolled the collective power of workers, proclaiming "when the $7 \frac{1}{2}$ lakhs $[750,000]$ workers in and around Calcutta were organised the police and the government would 'saläm' (salute) them". Continuing the reference to the army world, he argued that as the British government fortified its borders in Rangoon and Peshawar, so should the workers defend the entry points to the Port in Metiaburuz and Kidderpore during their strike. The various slogans of these meetings were "Lāl Jhanḍa kī jai" (Long live the red-flag), "Communist International kī Jai", "Mazdūr Kisān Hukumat kī Jaì" (Long live the workers' and peasants' government) and "Long Live Revolution". In other words, radical ideas in the communist repertoire were discussed repeatedly, openly and rather consistently. Such ideas would have sounded very unusual to labourers who had witnessed politicians' speeches before, but rarely did any of them talk about the strength of working class, let alone about a government of workers and peasants.

This recently formed union held its annual conference in April 1934. Sher Khan "hoisted the communist flag with ceremony". A.M.A. Zaman led a "squad of volunteers wearing red sashes with inscriptions of CPDWU and the hammer and sickle emblem" and marched in front of the flag. ${ }^{28}$ The resolutions that were passed were not only about the day-to-day problems of dockworkers. First of all, the changes in the Trade Disputes Act were criticised and the attitude of the government of India was "condemned" for renewing an act that helped continue "oppression of workers". The meeting popularised the May Day. Resolutions also warned the workers against the Municipal Corporation dominated by the Congress Party leaders. It reminded the audience that the corporation had called the 
police to shoot at workers during the scavengers' strike in 1928. Release of political prisoners and "labour workers" (which included the names of known communists) was also demanded. The annual conference of the union was an explicitly political affair, aiming to inform members of the important matters relating to the labour movement as well as the anti-colonial movement.

Meanwhile, as no concessions came for any of the workers' demands, the union took charge of the preparations for the strike, which included formation of a strike committee composed mainly of workers. ${ }^{29}$ The strike, in contrast to the union, involved a large majority of workers - between 8,000 and 15,000 out of the total 18,000 , according to different estimates presented in the Bengal Legislative Council, and it lasted for 20 days. Throughout the duration of the strikes, pickets were organised at the docks and at the offices of principal stevedores in charge of recruiting labour, and these often led to breakouts of violence since the police was heavily deployed in the defence of the stevedores and shipping interests. ${ }^{30}$ Contemporary newspapers described the scenes of strikebreakers, mainly recruited among outsiders: Anglo-Indian youth, Chinese labourers and Coconada workers. ${ }^{31}$ On the day the strike was to be discussed in the Bengal Legislative Council, around 7,000 strikers marched to the council house to present their petition. ${ }^{32}$ Some even attended the session, leading The Statesman to report about the "unaccustomed visitors [the dockers]". ${ }^{33}$ Because of the demonstrations and heavy picketing, the strike was seen as highly disruptive by contemporary observers, and as one of them observed, "the strike was a standing menace to the peace and tranquility of Calcutta not to mention the loss of trade", ${ }^{34}$ or to put it in another perspective, it was a very visible labour dispute.

\section{The entry of Suhrawardy and the making of a "white-union"}

The strike ended in very curious circumstances still, which were reported in The Statesman as "Maidan Meeting Scenes". According to the newspaper, it was declared over in a meeting of at least 5,000 workers. Rajani Mukherjee announced that the union had received an assurance from the shipping agents that there will be no victimisation if workers resumed work and so, they should resume work. ${ }^{35}$ After the strike was declared over by the activists of CPDWU, Huseyn Shaheed Suhrawardy, a member of the Bengal Legislative Council, arrived and told the workers that the shipping agents had refused to deal with the CPDWU because "it was influenced by extraneous considerations as distinct from the interests of the men" and the workers must form a new union under his leadership. ${ }^{36}$ This was unusual; it was one thing for a member of the Legislative Council to discuss labour issues but another to actually come and give speeches to thousands of workers. In any case, a new union called the Calcutta Dockers' Union (CDU) was formed with Suhrawardy as the president and it was duly recognised by the Master Stevedores' Association (MSA) "as a legitimate trade union [emphasis added] formed in the interests of the workers" ${ }^{37}$ The MSA refused to recognise unions such as CPDWU, which were "under communist or subversive 
influence". ${ }^{38}$ Subsequently, the CPDWU was even declared unlawful along with a number of "communist" organisations in the city, ${ }^{39}$ although, the stevedores remained sceptical of asking the workers to sign a document stating that they were no longer members of or had never been members of CPDWU as demanded by the shipping companies. ${ }^{40}$ The dockers won a reduction in working hours by an hour, ${ }^{41}$ and they were to be on board quarter of an hour before starting time (a reduction of 15 minutes from the previous starting time). ${ }^{42}$ In addition, a strike agreement was drawn between the shipping companies, the MSA and Suhrawardy's CDU covering the major terms of employment. ${ }^{43}$

Suhrawardy was a deeply conservative man but with a good grasp of street politics and intimate connections with the criminal world of Kidderpore. Belonging to an elite ashräf family, he was one of the rare Muslim politicians of the time to build links with the urban masses, which were to transform Muslim politics in Bengal in the decade leading to independence. As deputy mayor of Calcutta Corporation, he had been operating in the milieus of poor urban Muslims since the early 1920s. In one incident he enlisted the support of the Muslim butchers of Calcutta's Municipal Market through allowing the burial of their beloved $p \overline{i r}$ (saint) under the main drains of the meat section of the market, causing a lot of controversy amidst which the "butchers allegedly threatened bloodshed". ${ }^{44}$ During the 1926 Hindu-Muslim riots, Suhrawardy was found with other Muslim public figures like the Ariff brothers, inciting violence from the mosques. He was also said to have connections with the city's underworld, so much so that the British government had thought of externing him from the province. ${ }^{45}$ According to a biography penned by a family relative, he was so deeply affected by the riots of 1926 that he became one of the first to advocate the cause of Muslim communal interests ${ }^{46}$ and championed them right through to the Partition of India. He was the organising secretary of Muslim League, held the Labour portfolio in the first provincial government, was the minister of supplies during the Second World War and the premier of Bengal in the post-war government. The man straddled the world of the streets and that of high politics.

With the opening of the possibilities of representation of Muslim maritime trade unions in the new provincial legislative assembly, a range of Muslim politicians, including Suhrawardy, had started taking systematic interest in the trade unions of the dockers and the seamen in the early $1930 \mathrm{~s} .{ }^{47}$ By 1934 , Suhrawardy had successfully engineered a split in the most influential of seamen's trade unions, Indian Seamen's Union and Indian Quarter-Masters' Union, to form the rival Indian Quarter-Masters' Union. ${ }^{48}$ Through the establishment of CPDWU and the popular strike of 1934, dockers were developing a working-class identity; they were exploited but were capable of challenging exploitation, without the help of politicians like him. Not only did they participate in well-orchestrated strikes but (some) also in regular meetings and demonstrations, where symbols of revolutionary upturning of society such as the red flag and the hammer and sickle were openly displayed, songs of protest were sung and slogans such as "Mazdūr rājj" echoed. A politician like Suhrawardy was quick to realise the dangers of such selfexpression of workers and assertions of working-class politics. He vehemently 
opposed radical ideologies like communism and fashioned himself as the great champion of anti-communism. The colonial government in Calcutta, on the other hand, had found an experienced politician as interested as them in dampening the rising radicalism of labour movements.

Suhrawardy presented a note to Sir Harry Haig of the Bengal Legislative Council on the "labour question" in January 1934. Here, he argues that "constitutional labour agitation" under the then government was "futile" and therefore, labour is being "captured by the attractiveness of Communist slogans". According to him, "Government should further broadcast anti-communist literature through newspapers and pamphlets, both vernacular and English. Today the propaganda is all one-sided and in favour of 'mazdur raj"'. He added, "Persons must be trained with facts and figures, to speak and deliver lectures against Communism”. He went as far as to say that since the reds have their organisers in the constitutional trade unions, the "constitutionalists" should have their men in the "red organisations" and the government can be of "great help" ${ }^{49} \mathrm{He}$ was helping give a practical shape to the government's drive against the communists in the labour field, placing the emphasis on conducting anti-communist propaganda, presumably to give the workers another worldview for interpreting their experiences and struggles, and providing for loyalist men to function in workers' milieu. Such functions were, in fact, better envisaged and performed under the leadership of a native politician like Suhrawardy.

The case of dockers' strike shows that the colonial state was receptive to Suhrawardy's offers, so much so that, the president of the newly formed CDU, which was recognised by the employers as soon as it was formed, was Suhrawardy himself. The shipping employers didn't need to look far, they found a "trade union leader" from within the Bengal Legislative Council, who was even to climb the ladder of colonial governmental apparatus to serve as a labour minister from 1937. The collusion between the employers, the colonial government and a section of the nationalist politicians could not have been starker. Moreover, it was commented in the official correspondence that:

The strike was finally settled by the intervention of Mr. H.S. Suhrawardy, through whose good offices a new union working on lawful and constitutional [emphasis added] lines was formed. I refer to this for it shows that our action is in no ways directed against bona-fide labour [emphasis added] unions: we are fully satisfied that no such unions are affected by our action. ${ }^{50}$

In other words, a trade union which had been formed to break a popular strike was conveniently presumed to be "lawful" and "constitutional", barely a few months into its operation, never mind the criminal record of its president in successfully inciting religious violence. What follows will further shed light on the vacuity of the claim that CDU was a "lawful" trade union and explicate how in search of such "constitutional unions", the imperial authorities were aiding in the communalisation of politics in the labour world, at a time of rapid religious polarisation in Indian politics. 
To start with the CDU was able to, in effect, disorganise an important strike as well as the red-flag union that emerged with the strike. The former union declared its loyalties to the colonial state as it made it clear that it would operate on "constitutional lines" at several moments. In effect, this version of "constitutionalism" only went as far as avoidance of strikes until absolutely necessary. ${ }^{51}$

For next couple of years, CPDWU found it very difficult to survive, as the CDU established itself under employer patronage but also that of the newly formed Bengal provincial government. Given the casual nature of work at the docks the main and most efficient strategy was the control of recruitment in the docks. In the chipping department workers were asked to present chits from Suhrawardy himself to get work. Certain sirdars were intimidated and told that no men will be employed under them by Suhrawardy's men, who were also known as dalāls (agents). Workers were told that if they attend meetings they will not be employed. They were asked to join the CDU. The stevedores themselves openly told sirdars "to go over the side of Suhrawardy". Many of the sirdars lost their work because of the strike and were not re-employed for over two years. ${ }^{52}$ In 1937 again, 60 men were reported to be unemployed because the dalals had decided so. ${ }^{53}$ From then on, the two trade unions among the dockers would play a crucial role in securing work for coming decades. In 1949, an informant of Brocklebank Shipping line, reported, as a matter of fact, that the MSA mostly employed dockers of white union, while the dockers of red unions were employed mainly for government contracts. ${ }^{54}$

The second plank of mobilisation of labour adopted by the CDU was the instrumentalisation of religion among dockers who predominantly were of Muslim origin. The leadership of CDU, and Suhrawady in particular, became known for Islamic propaganda. Even though Suhrawardy himself was probably not religious, he was described by a contemporary as "totally unscrupulous, but not communal or religious. He ate ham and drank scotch and married a Russian actress". 55 Many workers perceived his politics to be deeply divisive and dangerous. For instance, Jafar Bhai remembered how Suhrawardy had suggested the Hindus and Muslims to march separately "at the foot of the monument at Dhurrumtolla" on the eve of the strike. ${ }^{56}$ Rahim Bhai argued that the policy of Suhrawardy would lead to communal riots and all the union funds he is collecting will be used to "bury the workers who would be killed in communal strife". ${ }^{57} \mathrm{He}$ also noted how Suhrawardy, on behalf of the workers, had attempted to create divisions through the platform of the legislature as the labour minister. He had said: "Dear Muslims, separate yourselves. A Hindu is after all a Hindu. Why do you go and mix with them?"58 Rahim Bhai concluded: "Thus they create divisions. All these leaders are the betrayers of the community" ${ }^{59}$ Calcutta's red-flag activists identified the white unions as a real obstacle in the dock areas. ${ }^{60}$ In fact, a major communal riot broke out in Titagarh jute mill town in 1938 in the aftermath of a general strike in the jute mills in 1937, as a direct result of communal propaganda. ${ }^{61}$ The instrument of religion could also serve the purpose of mobilising to defend the empire. In May 1940, the union held a "prayer meeting" attended by 1,500 dockers for the victory of Allies in the war and proclaimed its support for Britain. ${ }^{62}$ 
The depth of impact on dockers can only be appreciated with a sense of the growing communalisation of politics around them. CDU's politics of sowing religious division was part of a wider strategy adopted by the all-India Muslim League from the mid-1930s onward under Jinnah. ${ }^{63}$ Muslim League, a hitherto "aristocratic" party, ${ }^{64}$ which now formed an important part of a coalition of Muslim parties in Bengal Ministry, was hyperactively building a popular base in Eastern India, including among the poor peasants and workers. The Star of India, the leading Muslim English daily (patronised by the British), ${ }^{65}$ provides enough evidence to argue that the League was bidding for a mass base among the poor Muslims in the late 1930s for separatist politics. Labour issues were strikingly prominent in the The Star. ${ }^{66}$ The popular discontents with Congress Ministry ${ }^{67}$ in provinces such as Bihar and United Provinces were decried as ills of "Hindu rule" in headlines such as "Hindus blow up Muslim graveyard with dynamite" ${ }^{68}$ The Bengal Ministry's tenancy reforms, in fact spearheaded by Krishak Praja Party (KPP), ${ }^{69}$ were used excellently for mobilising support for the Muslim League among the peasants of Bengal and against the "Hindu" Congress. ${ }^{70}$ As part of the same exercise, seamen, who also came from the East Bengali Muslim peasanty, formed a special focus. The Star published calls for help through financial donations and doctors when floods struck East Bengal ${ }^{71}$ and a Seamen Bangia Sahajyo Samity (Seamen Flood Relief Association) was initiated. ${ }^{72}$ Splits were engineered in the rival Indian Seamen's Union, and 45 seamen and dockers (including some members of CPDWU), along with one of the most important leaders of the Indian Seamen's Union, Aftab Ali, were implicated in a criminal case; charges included "conspiring to kill" the acting shipping master. ${ }^{73}$ The jute mill workers, with a significant proportion of Muslims from Bihar and United Provinces, formed another important constituency for the League. ${ }^{74}$ By the end of the decade, League propaganda was bearing fruit; it could boast of Muslim politicians, such as Suhrawardy and Fazlul Huq, being received in demonstrations of tens of thousands of workers on several occasions, in Calcutta and even in the outlying jute towns. ${ }^{75}$ One such demonstration organised by a number of maritime unions associated with the Muslim parties was attended by 7,000, and "an address of welcome" was presented in a "silver casket" to Suhrawardy. ${ }^{76}$

The CDU was thus born and shaped as an employers' union under the twin patronage of shipping employers, and the Bengal Ministry, through the offices of the labour minister and Muslim League politician Suhrawardy. The colonial government aided one of the most reactionary politicians of the time to realise his vision of trade unionism; after all it was counterposed to "communist" unions. The union was one of the early ones of its kind and was to form part of a network of city-wide white unions, collectively part of the Bengal National Chamber of Labour, under the patronage of Suhrawardy.

As the subcontinent was drawn into the Second World War, and the colonial government's panic about labour reached new heights, the director of Intelligence Branch went as far as clearly stating that "white unions" are "officially sponsored". ${ }^{77}$ The official discussions within the provincial government concluded that white union (and/or constitutional unions) men should provide relevant 
information to local police officers, and employers must assist in the smooth functioning of what was now known as the "White-Union system", to allow for "concerted action" between "H.M. (C.\&L.) ${ }^{78}$ - Police - Labour Commissioner Employers - White Union". ${ }^{79}$ The network for state repression of the labour movement could not have been more clearly laid out.

\section{Of violence and volunteers}

Even so, the CPDWU was never entirely silenced, it re-emerged as Dock Majdoor Union (DMU) to avoid illegality. As the rising prices and the uncertainties of the war added to the pressing material issues of the dockers, they contested the CDU's leadership and attempted to give the union a more militant shape. By 1941, the fragile coalition of Muslim parties in Bengal Ministry was witnessing another split and had ramifications for the balance of forces between the various Maritime trade unions, proving fortunate for the DMU to some extent. ${ }^{80}$ Popular collective action continued to face enormous obstacles, but labour militancy was not so easily suppressed; it only found narrower and more dangerous channels.

The rivalries between the two unions intensified and, most significantly, were being imposed through armed as well as externally funded (to whatever extent) "Volunteers". Historians have noted the proliferation of Volunteer groups in interwar period in the Indian context. ${ }^{81}$ Paramilitary groups, often armed and uniformed, were organised by political parties across the spectrum on national and regional scales to fulfil the urgent needs of defence against both the perceived internal and external enemies. ${ }^{82}$ The term "paramilitary" has been used here to underline that such groups "sought state power or, proposed ethnic nationalism" and attempted to take on state functions in a period that became crucial in claim-making by conflicting nationalist forces. ${ }^{83}$ Many such groups ${ }^{84}$ became infamous for their dictatorial post-colonial visions, overt militarism and their espousal of fascist ideologies, methods and symbolisms. Nandini Gooptu has been one of the few historians to focus on the role of Volunteers among the urban poor; the interactions of Volunteers and labour politics have hardly received any attention. ${ }^{85}$

As early as 1934, the intelligence noted the practice of a march led by A.M.A. Zaman in the docklands, under the banners of "workers of the world unite". In fact, since the inception of the DMU, formation of a Volunteer corps was considered necessary, as Zaman argued in a speech "not for any breach of the peace but to keep order in their meetings and processions". ${ }^{86}$ A resolution to form Jamiruddin Fauj was passed in July 1938 in the union's meeting. ${ }^{87}$ It was named after a textile worker Jamiruddin, who had been murdered for not joining a company union. ${ }^{88}$ In the late 1930s, Volunteer groups emerged in several industries; intelligence reports for the year 1938-39 mentioned a number of such groups mainly associated with Congress-linked Bengal Labour Association (BLA), Indian Seamen's Union and the two unions of dockers. ${ }^{89}$ The labour Volunteers associated with the BLA disappeared from the radar by $1940 .{ }^{90}$ In fact, Jamiruddin Fauj and the labour militia of CDU lasted for the longest duration, pointing to the strength of organised 
working class in the docklands as well as the higher prevalence of violence in labour relations.

Initially, such groups were set up to settle inter-union rivalries, but their field and scope of operation quickly expanded. Volunteers associated with both the dockers' unions enjoyed the patronage and functioned as part of a wider network of such groups in the city, which were in turn connected to national political parties. Jamiruddin Fauj at the docks was part of a citywide body organised by the Bengal Labour Party, whose members were often seen in public meetings "clad in red-shirts, khaki shorts and Gandhi cap". ${ }^{91}$ They practised läthi-play, held regular drills and had access to free uniforms at times. The organisers and office-bearers sometimes received pocket money. Most interesting are the links formed with two militaristic political organisations, which had found affinities with the Nazis. Bengal Labour Party actively sought alliances with Subhas Chandra Bose's ${ }^{92}$ Forward Bloc and campaigned in favour of it among workers, and in return, Bose promised money for the party's Volunteers. ${ }^{93}$

Even more striking are the Bengal Labour Party leaders' ambitions of forming alliances with the Khaksar Tehreek (movement of the humble), the most militant of anti-colonial Muslim paramilitary groups in the interwar period. Khaksar leadership idealised dictatorship as a way forward for society, and its leader Allama Mashriqi (sage of the east) even claimed to have inspired the Nazis. The Khaksars carried spade on their shoulder, in a remarkable similarity to the symbols of Nazi Reichsarbeitsdienst (Reich Labour Service). Mashriqi advocated the domination of Islam through an organisation based on the values of militarism, obedience to the leader and unity. ${ }^{94}$ In 1939, the intelligence mentioned that Khaksar had a strength of 3,000 in Calcutta alone, and it was the only Muslim Volunteer group that was labelled as "specially dangerous". ${ }^{95}$ It was especially active in Kidderpore. The Khaksar uniform included khaki coats, breeches, belts, boots, putties, spades and Reza Shah Pahlavi caps. ${ }^{96}$

The Volunteers of the CDU, whose uniform included blue shirts, caps and lathis, ${ }^{97}$ formed part of closely associated Volunteer groups organised on religiousnationalist basis like the Muslim National Guard and the Khilafat Guards. ${ }^{98}$ Even Khaksar men participated in some such joint activities. ${ }^{99}$ Even though Khaksar and Khilafat volunteers had existed previously, the basis of an all-India Muslim League National Guard was laid by Jinnah in 1937. In Calcutta, the numbers of League and Khilafat Guards remained in few hundreds between 1938 and 1942. ${ }^{100}$ They paraded during demonstrations of Bengal Ministry, or during Muslim League sessions, they attempted to police such mobilisations. ${ }^{101}$ They protected the mosques, arranged relief measures even for events in Turkey, agitated for the Palestine question, demanded "boycott" of Congress and above all, the fight for protection of Islam was their battle cry. ${ }^{102}$ These Volunteers had comparatively elaborate uniforms: League volunteers' uniform included green shirts, white shorts/pyjamas, green fatigue caps and half läthis. ${ }^{103}$ The Khilafat volunteers wore khaki coats and shirts, khaki round caps with a crescent and carried half läthis and white badges.

In fact, Kidderpore emerged as one of centres of the activity of the Muslim League Volunteers, reflecting the close and the kind of relationship that the 
Muslim League had fostered among the local habitants, a significant proportion of whom were maritime workers. For instance, one Muslim League volunteers meeting in the neighbourhood was attended by as many as 800 , a number of "parties" from all over Calcutta arrived, including members of Khaksar and Khilafat. Most strikingly, some of the local ones were named as such: Kidderpore Muslim League (Boys group) under the leadership of Noor Mohammed, Hakim Liaqot Hossain's Party of Watgunge street, Abdul Latif Ostad's Party of Orphangunge Market, Kidderpore, Abdul Hakim and Bulaki's Party of Mominpore, Kidderpore, testifying to organisations constituted on a local level in the dock neighbourhood under a one-man leadership. The highlight of the meeting was "physical display", which included a stick, sword and bayonet play, and Jiu Jitsu. ${ }^{104}$ The colonial government was strikingly tolerant of such displays of arms on the streets; these Volunteers were repeatedly labelled as "not dangerous", as opposed to the "potentially dangerous" Jamruddin Fauj and Khaksar Tehreek. ${ }^{105}$

Such popularity of a range of Volunteer groups in the docklands demands closer attention towards their function in the social and political life of maritime workers. An incident outside the office of a stevedore, on a payday in November 1941, exemplifies the role such groups came to play, revealing the ongoing criminalisation of labour politics, as well as the militant assertions of working-class anti-colonialism. Ziauddin Ahmed, nephew of Suhrawardy, and the secretary of the CDU, provided the following description of the incident. As the workers were being paid, a sirdar was pushing them to contribute towards the war fund. When a worker agreed to pay, the information was passed on to "organisers of Red-flag dressed in red shirt and cap" who were waiting outside the office. "At this the agitators became furious and assaulted Jaffar Khan as soon as he came out of the office". Ziauddin further claimed that the incident had "created a great panic in the minds of the loyal labourers", who in his view did not feel safe enough to contribute to the war fund anymore. The incident was narrativised differently in an official police inquiry. It revealed that there were clashes on the day after Badiur Rahman, a well-known worker-militant belonging to DMU, raised objections against deductions for the war fund stating that this union had a separate fund for aid to the Soviet Union. Several workers from both the unions were injured and arrested. Importantly, the intelligence didn't mention the presence of uniformed workers in contradiction with the report of Ziauddin. ${ }^{106}$ Yet, the latter's version cannot be easily dismissed. Given that Jamruddin Fauj had been built for precisely the functions of armed defence of the red union, it is probable that the Volunteers were involved in the incident.

The main point of significance is that DMU worker-militants, whether uniformed or not, had taken up the risky and internationalist cause of opposing the war through not paying for the Allies war fund. This was not a one-off incident; small groups of workers had been agitating for the cause in the dock neighbourhoods. In one instance, eight workers of the union made a procession and one of them made a ten-minute anti-war speech. We do not have access to the full speech; the police only recorded that he had argued that workers shouldn't subscribe the war fund, since they were already paid so little, in front of a hundred 
workers. Dockers proclaimed, in a number of speeches, that they were collecting for the Soviet Union, making it clear that they were also contributing towards a larger issue if the rival union was collecting money to fight fascism under the slogans of "Hitler Barbād (destroy Hitler)". ${ }^{107}$ They not only voiced anti-war opinions against supporting the British but felt (physically) strong enough to use violence against their opponents on an issue as ideologically charged as taking sides in the war. All this at a time when the government had an extremely repressive policy against any expressed scepticism let alone criticism of the war effort. ${ }^{108}$ As far as we can see, this was not as a result of worker militants relying on the anti-war feelings of the wider layers of workers. It is more plausible to say that small groups of armed men, probably belonging to the Volunteers discussed earlier were imposing their power on rest of the workers. Moreover, there are indications that DMU was receiving protection from the Chief Minister Fazlul Huq ${ }^{109}$ who was rallying the dockers against Suhrawardy at a time of a ministerial crisis. Historians like Gooptu have seen Volunteers as a crystallisation of subaltern radicalism in the face of perceived passivity of the mainstream nationalist parties. ${ }^{110}$ This incident adds a crucial dimension by showing that such resistance was an expression of the few, such acts of resistance involved a handful of individuals, organised in disciplined and even armed groups, who relied on intimidation and violence to make their point of view publicly visible to the rest as opposed to popular actions. This was not the only incident. In the same year, the intelligence noted the high frequency with which the two rival unions clashed violently. ${ }^{111}$

In the same year as dockers associated with the Bengal Labour Party were showing their muscle power to publicly defend their lack of support for the British in the Second World War, an intelligence report noted that regular parades of Khaksar were being held close to seamen's lodging houses in the docklands, where they were seen wearing uniforms and belćas (spades). Notably, several of them even belonged to the Indian Seamen's Union, ${ }^{112}$ which was close to DMU and Bengal Labour Party. ${ }^{113}$ The same reports are suggestive of motivations for undertaking the risks of participating in such militant and militaristic anti-British spectacles. To start with, the reports all refer to a brief period during the war - May-June 1941, when Arab Nationalist Rashid Ali al-Gailani had just led an anti-British military coup in Iraq. Rashid Ali was seen as a comrade by the local Khaksars. The event had raised hopes that Khaksars too could play such a role in the Indian independence; an ex-sailor had even set up a shop in Kidderpore bazaar, from where he spread such ideas. ${ }^{114}$ He was not alone, the intelligence worryingly noted that the cause of Rashid Ali, who "had been acting more in the interests of Islam than for any other power", had found favour among the local seamen, many of whom had just returned from the Middle East with a "defeatist mentality". 115

In other words, notwithstanding the state's claims of assisting constitutional trade unionism, working-class anxieties, aspirations and militancy were finding outlet into a bewildering mix of political causes including varied visions of anticolonialism. Moreover, even the radical labour leadership, Bengal Labour Party in this case, not only advocated the defence of the Soviet Union somewhat under 
the protection of Bengal Ministry, it was already collaborating with Subhash Chandra Bose and was also hoping for alliances with Khaksar Tehreek. The latter was probably due to the pressures of party's seamen base. Thus, even as labour militancy was outpouring in widening visions of anti-colonialism and crystallising in red-flag trade unionism, the latter was already leaning on the forces of emergent nation(s) ${ }^{116}$ as manifest in the Volunteer groups, to assume, impose and sustain the balance of power on its side.

The deep anxieties of colonial state vis-à-vis a rising radical labour movement made for strange bedfellows, forcing collaborations with the rising star of Bengal Muslim League - Suhrawardy, a popular, elite and conservative politician who had proven adept at instrumentalising and fanning religious fanaticism for high politics. The efforts at quelling a red-flag trade union born out of popular collective mobilisation opened the way for politics of patronage of the powerful communitarian parties, and of communalisation, abetting the building of a popular base for the Muslim League in the docklands. Notwithstanding the highly militant record and revolutionary claims throughout the period, red-flag trade unionism proved vulnerable to pressures of its political climate. Access to channels of emergent nation(s) was becoming important in running the show even for the most radical of unions. The modus operandi of Volunteer groups in the docklands exemplify such trends, pointing to the violence of the few becoming a determining factor in labour politics, even if for the time being. The post-war period saw another moment of collective mobilisation. Even so, the violent rivalries between CDU and DMU had been deeply entrenched. In the late 1940s, the former smoothly shifted its allegiances to the ruling Congress Party after independence and became an instrument in the hands of the new rulers for countering labour radicalism. Ironically enough, the CDU, which had been nurtured by the torchbearers of Muslim separatism, now found it opportune to cast DMU as belonging to "Pakistani communists". ${ }^{117}$

\section{Notes}

1 The chapter discuss the dockers employed through the stevedores, who provided skilled loading and unloading labour directly to the shipping companies. Another set of dockers were employed through the Bird and Company, the single largest contractor for those working at the sheds and warehouses. Their politics followed a different course and is not the subject matter of this chapter.

2 The characterisation "red-flag" or simply "red" was attributed by the employers and government officials, and in popular parlance, to a host of socialist and communist groups, and the associated organisations and unions that proliferated in this period at the port and in fact, in other industrial sites of Calcutta.

3 The most important of a series of trials in British India which attempted to nip the communist movement in the bud through charging communists with conspiring to deprive the king-emperor of sovereignty over British India. As part of the Meerut trial, the state attempted to outlaw communist ideology as such, by linking its adherents to the Soviet Union. Contrary to its purpose, the trial became key in launching communist politics across British India even as a number of prominent leftists were incarcerated. For details see Ali Raza, "Separating the Wheat from the Chaff: Meerut and the Creation of 'Official' Communism in India," Comparative Studies of South Asia, Africa and the Middle East 33, no. 3 (2013): 316-30. 
4 It is important to note that these ideological divisions were not as clear-cut at the time. Even though the colonial government branded all those militant political groups active among labour as communists, they often held ambivalent and conflicting ideas as to the role of working-class revolution vis-à-vis the nationalist movement in the anti-colonial struggles.

5 West Bengal State Archive (Hereafter, WBSA), File no. 274/35, Cancellation of the certificate of registration under article 8 of Indian Trade Unions Act, 1926 - Question of amending the Act.

6 WBSA, File no. 304/35, Question in Assembly: Communist Organisations.

7 Nirban Basu, Trade Union, Working Class Politics and Protest (Kolkata: Progressive Publishers, 2019), 34-35. Subho Basu, Does Class Matter? Colonial Capital and Workers' Resistance in Bengal, 1890-1937 (New Delhi and Oxford: Oxford University Press, 2004), 259-61.

8 Ibid.

9 At the outset, it is important to define communalism, a term that holds specific meanings in the Indian subcontinent.

Communalism refers to politics based on defending the interests of a religious community, as against the (perceived or real) threat of another, which often led to hatred, riots, and organised violence. Gyan Pandey shows how the politics of religion acquired the pejorative label of communalism from the $1920 \mathrm{~s}$, as a new vision of Indian nationalism took shape that attempted to rise above primordial divisions like religion and caste.

Gyanendra Pandey, The Construction of Communalism in Colonial North India (New Delhi and Oxford: Oxford University Press, 2006). For a historical and conceptual discussion of the term.

10 Janam Mukherjee, "Hungry Bengal: War, Famine, Riots and the End of the Empire, 1939-1946" (Doctoral diss., University of Michigan, 2011), 226-27.

11 Kenneth Mcpherson, "The Muslims of Calcutta, 1918 to 1935: A Study of the Society and Politics of an Urban Minority Group in India" (PhD diss., Australian National University, 1972), 56-57.

12 Nirban Basu, The Political Parties and the Labour Politics, 1937-47 (Kolkata: Minerva, 1992), 116. For instance Mohammad Daud, an influential labour leader of the seamen, kept his distance from Muslim politicians as did Aftab Ali.

13 For instance, see Sabyasachi Bhattacharya, The Defining Moments in Bengal: 1920 1947 (New Delhi: Oxford University Press, 2014), Ch. 6. For the rise of Hindu Communalism, in the same period, see Joya Chatterji, Bengal Divided: Hindu Communalism and Partition, 1932-1947 (Cambridge: Cambridge University Press, 1994).

14 Suranjan Das, "The 1992 Calcutta Riot in Historical Continuum: A Relapse into ‘Communal Fury'?” Modern Asian Studies 34, no. 2 (2000): 281-306, 294.

15 Basu, Trade Union, 332. According to one reference out of a total of 14,000 dockers, 9,000 were approximated to be Muslims from UP and Bihar, and 5,000 were Hindus from Orissa.

16 Royal Commission of Labour in India (hereafter, RCLI), v. pt. 2, 436.

17 Mcpherson, "Muslims of Calcutta," 166.

18 For instance, see Tazeen M. Murshid, The Sacred and the Secular: Bengal Muslim Discourses, 1871-1977 (Oxford: Oxford University Press, 1995); Shila Sen, Muslim Politics in Bengal, 1937-1947 (New Delhi: Impex India, 1977); Harun-or-Rashid, The Foreshadowing of Bangladesh: Bengal Muslim League and Muslim Politics, 19061947 (Dhaka: The University Press, 2003).

19 RCLI, v. pt. 2, 436.

20 University of Gottingen Online Database [UGOD, hereafter], Monthly Reports of the Indian Branch Office of the International Labour Organisation, January 1933, Maritime Affairs, d) Hours of Work and Age of Employment of Dock Labourers: Efforts to elicit Opinion prior to Legislation, 70 
21 UGOD, Monthly Reports, October 1929, Conditions of Labour, Dockworkers' strike Karachi, 18-19; April 1931; Conditions of Labour, Burmese Dock Labourers' Strike, Rangoon, 35-36; March, 1932, Maritime Affairs a) Dock Workers' Strike Bombay b) Dock Yard Workers' Strike, Madras, 77-79; December 1934, b) Dock Workers' Strike, Calcutta, 68-69; November 1937, Conditions of Labour, i) Bombay Dock Workers strike, 26.

22 WBSA, File no. 553, Prosecution of A.M.A, Zaman and others . . . in connection with the annual conference of Port and Dock Workers Union, Port and dockworkers Annual Conference 29 April 1934.

23 Ibid.

24 John Patrick Haithcox, Communism and Nationalism in India: M.N. Roy and Comintern Policy, 1920-1939 (Princeton, NJ: Princeton University Press, 1971), 175.

25 All the descriptions of activists and their activity in this paragraph are based on the file (unless indicated otherwise): British Library (Hereafter, BL), Action taken under criminal law amendment Act 1908 against communist organisations, $\mathrm{L} / \mathrm{P} \& \mathrm{~J} / 12 / 474$, Note on the Calcutta Port and Dock Workers' Union, 38-41.

$26 \mathrm{BL}, \mathrm{L} / \mathrm{P} \& \mathrm{~J} / 12 / 474$, Action taken under criminal law amendment Act 1908 against communist organisations, R.S.N. \& I.G.N. Ry. Companies Labourers and Workers' Union, 64.

$27 \mathrm{BL}, \mathrm{L} / \mathrm{P} \& \mathrm{~J} / 12 / 474$, Action taken under criminal law amendment Act 1908 against communist organisations, A note on the Calcutta Port and Dock Workers' Union, 41-51. The description of the meetings between January and December 1934 is from this document unless otherwise stated.

$28 \mathrm{BL}, \mathrm{L} / \mathrm{P} \& \mathrm{~J} / 12 / 474$, Action taken under criminal law amendment Act 1908 against communist organisations, A note on the Calcutta Port and Dock Workers' Union, 43.

29 Ibid.

$30 \mathrm{BL}, \mathrm{L} / \mathrm{P} \& \mathrm{~J} / 12 / 474$, Action taken under criminal law amendment Act 1908 against communist organisations, A note on the Calcutta Port and Dock Workers' Union; Bengal Legislative Council Proceedings 1934 [Hereafter, BLCP], Motion of Adjournment, 105.

31 BLCP, Motion of Adjournment, 106.

32 The Statesman, [date unclear].

33 The Statesman, December 13, 1934.

34 BLCP, Motion of Adjournment, 120.

35 The Statesman, December 17, 1934.

36 Ibid.

37 National Maritime Museum in Greenwich, London (Hereafter, NMM), IPC/3/12, Calcutta Liners Conference, Minutes of the proceedings of a meeting of the Calcutta Liners Conference held at the Royal Exchange, 3 Clive street, Calcutta on the 1 April 1935, Calcutta Port and Dock Workers' Union.

38 Ibid.

$39 \mathrm{BL}, \mathrm{L} / \mathrm{P} \& \mathrm{~J} / 12 / 474$, Action taken under criminal law amendment Act 1908 against communist organisations.

40 NMM, Calcutta Liners Conference, Minutes of the proceedings of a meeting of the Calcutta Liners Conference held at the Royal Exchange, 3 Clive street, Calcutta on the 1 April 1935, The Calcutta Port and Dock Workers' Union.

41 Trade Union Record, February 1935; KPTMA, 6612/2/II, Calcutta Port Trust Worker.

42 NMM, Calcutta Liners Conference, Minutes of the proceedings of a meeting of the Calcutta Liners Conference held at the Royal Exchange, 3 Clive street, Calcutta on the 13 May 1935, Stevedores Labour: Hours of work under the strike agreement.

43 NMM, IPC/3/12, Calcutta Liners Conference, Minutes of the Proceedings, reports for the year 1935 .

44 McPherson, "Muslims of Calcutta," 148-49. 
45 Ibid., 167, 171-72; Chatterji, Bengal Divided, 81.

46 Begum Shaista Suhrawardy Ikramullah, Huseyn Shaheed Suhrawardy, A Biography (New Delhi: Oxford University Press, 1991), 25-26.

47 Mcpherson, "Muslims of Calcutta," 249-51.

48 Ibid.

49 PC Joshi Archives of Contemporary History, JNU, New Delhi, Labour 1934/ 70, Notes on the Labour Question and the Congress Parliamentary Board by Shri H.S. Suhrawardy, M.L.C.

50 WBSA, File no. 304/35, Question in Assembly: Communist Organisers.

51 Kolkata Police Museum (Hereafter, KPM), KPM/SB/03128/05, Calcutta Dockers' Union, 1940; KPM/SB/03127/05, Calcutta Dockers' Union, 1938.

52 WBSA, File no. 105/35, Proposed prosecution of Rajani Mukheriji and Shamsul Huda for objectionable speeches under section 124 A of the Indian Penal Code.

53 WBSA, File no. 389/37, Proposed prosecution of Abdul Rahim@ Rahim Bhai.

54 Merseyside Maritime Museum, Liverpool, B/BROC/5/2/11, Report by Mr E.C. Cottingham and Mr. E.A. Newland on their visit to India and Ceylon, etc. 1948-49.

55 Chatterji, Bengal Divided, 84.

56 WBSA, File no. 105/35, Proposed prosecution of Rajani Mukherji and Shamsul Huda for objectionable speeches under section $124 \mathrm{~A}$ of the Indian Penal Code.

57 Ibid.

58 WBSA, File no. 105/35, Proposed prosecution of Rajani Mukherji and Shamsul Huda for objectionable speeches under section $124 \mathrm{~A}$ of the Indian Penal Code.

59 Ibid.

60 KPM/SB/00-90/05, Labour News Service; KPM/SB/00513/05, Bengal Labour Party Trade Union Activities, Dock Mazdoor Union (BLP), August 1939.

61 Basu, Does Class Matter, 258-59.

$62 \mathrm{KPM} / \mathrm{SB} / 03128 / 05$, Calcutta Dockers' Union, 1940.

63 A number of scholars have written about the rise of Muslim separatist politics from the mid-1930s onward under the leadership of Muslim League. A trend which eventually culminated in the partition of the subcontinent, in the face of Congress intransigence. Separatist politics refers to the nationalism of religion, or communalism, which increasingly came to eclipse other trends in Muslim politics. It asserted that Muslims were a separate nation on the Indian subcontinent and foregrounded the idea of a Muslim "community" as something homogenous. The other side of the coin was the rise of Hindu communalism and the hardening of religious differences within the subcontinent's population, which broke out in a number of religious riots.

For United Provinces, see Francis Robinson, Separatism among Indian Muslims: The Politics of the United Provinces' Muslims, 1860-1923 (Oxford India Paperbacks. New Delhi: Oxford University Press, 1993); Pandey, The Construction of Communalism in Colonial North India; for Bengal, Sen, Muslim Politics in Bengal, 1937-1947.

64 Mcpherson work is the only one of its kind that charts out the rise of Muslim politics from a marginal trend in 1918-19 to a major urban political force in Bengal politics, with a base among merchants, artisans, ratepayers and trade unionists by 1936 .

65 Basu, Does Class Matter, 232-33.

66 See for instance, The Star, July 15, 1939; August 4, 1938.

67 The Star, July 12, 1938.

68 The Star, August 3, 1938.

69 Chatterji, Bengal Divided, 105. Krishak Praja Party (KPP), literally the Peasants and Tenants Party, was a populist rich-middle peasant party and was not an overtly communal organisation.

70 Chatterji, Bengal Divided, 121-22.

71 The Star, September 28, 1938.

72 The Star, September 19, 1938.

73 Advance, August 12, 1938; July 11, 1938. KPM/SB/00225/05, Search of 4 Puddapukur Square on 24 January 1940 (Dock Majdoor Union). 
74 The Star, September 19, 1938; August 8, 1938; August 11, 1938; August 15, 1938.

75 Ibid.

$76 \mathrm{KPM} / \mathrm{SB} / 03127 / 05$, Dockers' Unions.

77 KPM, SB File no. SM-572/40, Action under the defence of India Rules against Communist and Labour agitation.

78 Her Majesty (Commerce and Labour), a reference to the Labour and Commerce Department of the Bengal Ministry.

79 KPM, SB File no. SM-572/40, Action under the defence of India Rules against Communist and Labour agitation.

$80 \mathrm{KPM} / \mathrm{SB} / 03128 / 05$, Calcutta Dockers' Union, 1940.

81 Nandini Gooptu, The Politics of the Urban Poor in Early Twentieth-Century India (Cambridge and New York: Cambridge University Press, 2001); Markus Daechsel, The Politics of Self-Expression: The Urdu Middle-Class Milieu in Mid-Twentieth Century India and Pakistan (London and New York: Routledge, 2006); Ian Talbot, "Crowds, Ceremonials and State Symbolism: The Role of the Muslim National Guards in the Pakistan Movement," in Freedom's Cry: The Popular Dimension in the Pakistan Movement and Partition Experiences in North-West India, ed. Ian Talbot (Karachi: Oxford University Press, 1996), 59-80; Ian Copland, "Communalism' in Princely India: The Case of Hyderabad, 1930-1940," Modern Asian Studies 22, no. 4 (1988): 783-814.

82 For an account that brings an all-India perspective to the volunteer groups and places the history in that of global fascism, see Ali Raza and Franziska Roy, "Paramilitary Organisations in Interwar India," South Asia: Journal of South Asian Studies 38, no. 4 (2015): 671-89.

83 Ibid., 673-74.

84 A conservative estimate suggests that the total membership of all volunteer groups was 94,247 in 1940. Raza and Roy, 685.

85 Gooptu, The Politics of the Urban Poor.

86 WBSA, File no. 553/1934, Prosecution of A.M.A. Zaman and the others.

$87 \mathrm{KPM} / \mathrm{SB} / 00716 / 05$, Gist of the review of the weekly "Sathi" dated 27 July 1938.

$88 \mathrm{KPM} / \mathrm{SB} / 00716 / 05$, "Mazduro ke liye comrade Jamir shaheed (Comrade Jamir becomes a martyr for the cause of workers", in Sathi.

$89 \mathrm{KPM} / \mathrm{SB} / 02574 / 05$, Volunteer Organisations, 1938.

90 Ibid.

$91 \mathrm{KPM} / \mathrm{SB} / 00513 / 05$, Bengal Labour Party - Trade Union Activities.

92 Subhas Chandra Bose, a well-known nationalist leader from Bengal, was a proponent of armed struggle against the British and was a leading figure of the left-wing in Indian National Congress. During the Second World War, Bose, who had been an admirer of Mussolini, is most known for his collaboration with the Nazis and setting up the Indian National Army (INA) in South East Asia.

$93 \mathrm{KPM} / \mathrm{SB} / 00513 / 05$, Bengal Labour Party - Trade Union Activities.

94 Raza and Roy, 680-88.

$95 \mathrm{KPM} / \mathrm{SB} / 02574 / 05$, Volunteer Organisations, 1938.

96 Ibid.

97 Ibid.

$98 \mathrm{KPM} / \mathrm{SB} / 02423 / 05$, Muslim League National Guard.

99 Markus Daeshsel, "Visionary of Another Politics: Inayatullah Khan 'al-Mashriqi' and Pakistan," in Muslims against Muslim League, ed. Ali Usman Qasmi and Megan Eaton Robb (Cambridge: Cambridge University Press, 2018). The article discusses the relationship of Khaksars with the other Muslim nationalist parties. Khaksar leadership had a vision of united Hindustan and thus, sustained a hostile relationship with the Muslim League.

100 Ibid.

$101 \mathrm{KPM} / \mathrm{SB} / 02423 / 05$, Muslim National Guard, 1938, Extract from a note from D.C., S.B. to C.S., H.D., giving brief histories and an account of the recent activities of major volunteer organisations operating in Calcutta. 


\section{Prerna Agarwal}

102 KPM/SB/02423/05, Muslim National Guard, 1938.

$103 \mathrm{KPM} / \mathrm{SB} / 02574 / 05$, Volunteer Organisations, 1938.

$104 \mathrm{KPM} / \mathrm{SB} / 02423 / 05$, Muslim National Guard, 1938, Kidderpore Muslim League.

$105 \mathrm{KPM} / \mathrm{SB} / 02574 / 05$, Volunteer Organisations, 1938.

$106 \mathrm{KPM} / \mathrm{SB} / 03128 / 05$, Calcutta Dockers' Union, 1940.

107 Ibid.

108 Sanjoy Bhattacharya, Propaganda and Information in Eastern India, 1939-1945: A Necessary Weapon of War (Richmond: Curzon, 2000), 135-39; Prerna Agarwal, "Planting the Red-flag: Early Communists and the Politics of Labour at the Port of Calcutta, 1920s-1940s" (Unpublished PhD diss., Kings College London, 2018). For accounts of state repression of meetings and processions in the wartime.

$109 \mathrm{KPM} / \mathrm{SB} / 03128 / 05$, Calcutta Dockers' Union, 1940.

110 Gooptu, The Politics of the Urban Poor, 416-18.

$111 \mathrm{KPM} / \mathrm{SB} / 03128 / 05$, Calcutta Dockers' Union, 1940, Re: Creating frictions and parties among the Dockers' labourers by the interested Stevedores.

$112 \mathrm{KPM} / \mathrm{SB} / 03123 / 05$, Shipping Strikes, 1938, Memorandum, Central Intelligence Office, 20 June 1941.

113 KPM/SB/03123/05, Shipping Strikes; KPM/SB/03128/05, Calcutta Dockers' Union, 1940. The Dock Majdoor Union was even “merged" with the Indian Seamen's Union temporarily in 1938.

$114 \mathrm{KPM} / \mathrm{SB} / 03123 / 05$, Seamen's Movement, 12 June 1941.

$115 \mathrm{KPM} / \mathrm{SB} / 03123 / 05$, Seamen's Movement, 5 June 1941.

116 The terminology is used to underline that the various nationalist parties (in provincial government and outside) were assuming some state functions in the lead up to independence.

117 KPM/SB/5891/09, Calcutta Dockers’ Union, 1949. 